\title{
EFFECT OF NITROGEN LEVELS AND WEED MANAGEMENT ON YIELD PERFORMANCE OF BRRI HYBRID DHAN3 UNDER AWD IRRIGATION SYSTEM
}

\author{
MKA Bhuiyan*, Md. Mostofa Mahbub, Lutfun Nahar, Md. Zakaria Ibne Baki \\ Bangladesh Rice Research Institure, Joydebpur, Gazipur-1701, Bangladesh \\ Corresponding Author: bhuiyan072003@yahoo.com
}

Key wards: Weed management, Herbicide, Weed abundance and Grain yield

\begin{abstract}
Experiment was carried out at the Agronomy field of Bangladesh Rice Research Institute, Gazipur, during the period from December 2014 to May 2015 to investigate the response of different levels of $\mathrm{N}$ and methods of weeding on weed abundance and grain yield of BRRI hybrid dhan3 under alternate wetting and drying (AWD) irrigation condition. The treatments consisted of five $\mathrm{N}$ levels viz., $0,60,120,180$ and $240 \mathrm{~kg} \mathrm{~N}$ ha $^{-1}$ and four different weed control methods viz., Pre-emergence herbicide followed by $1 \mathrm{HW}$, Pre-emergence followed by post emergence herbicide, Weed free by 3 hand weedings and Unweeded (control). The experiment was laid out in factorial RCB design with three replication. Pre-emergence application of prefer 18WP (Bensulfuran Methyl + Acetachlor) and post emergence herbicide Dhaman 300wp (Bispyribac sodium $18 \%+$ Bensulfuran methyl 12\%) followed by one hand weeding effectively control all weeds (78-93\%). In the experimental field, sedges and grass weeds were highly dominant over treatments. Based on summed dominance ratio (SDR), the most dominant weed species could be arranged in the order of Echinochloa crus-galli $>$ Scirpus juncoides $>$ Cynodon dactylon $>$ Cyperus difformis $>$ Marselia minuta $>$ Monochoria vaginalis. Interaction of nitrogen levels and weeding methods had significant response on yield and yield components of hybrid rice. The highest $(7.61 \mathrm{t}$ $\mathrm{ha}^{-1}$ ) grain yield was obtained from the combination @ $180 \mathrm{~kg} \mathrm{~N}^{-1}$ with weed free treatments. Comparable higher grain yield was obtained from the combination of pre emergence herbicide of bensulfuranm methyl + acetachlor) + one hand weeding with $180 \mathrm{~kg} \mathrm{~N}$ ha $\left(7.48 \mathrm{t} \mathrm{ha}^{-1}\right)$ and the combination of pre + post-emergence herbicide (Bispyribac sodium 18\% + Bensulfuran methyl 12\%) with $180 \mathrm{~kg} \mathrm{~N}^{-1}\left(7.56 \mathrm{t} \mathrm{ha}{ }^{-1}\right)$. The estimated optimum dose of nitrogen for Pre EH, Post EH and 3HW (weed free) were $173,189.1$ and $189.4 \mathrm{~kg} \mathrm{~N}^{-1}$ respectively for BRRI hybrid dhan3 under AWD irrigation system.
\end{abstract}

\section{Introduction}

Rice (Oryza sativa L.) is one of the most important cereal crops in the world. In Bangladesh, the area and production of hybrid rice in boro season were about 6.36 lac hectares and 30.09 lac metric tons, respectively (AIS, 2015). The population of Bangladesh is still growing by two million every year and may increase by another 30 million over the next 20 years. Thus, Bangladesh will require about 27.26 million tons of rice for the year of 2020. But the average yield of rice is $4.50 \mathrm{t} \mathrm{ha}^{-1}$ in Bangladesh, whereas the average rice yield in China, Japan and Korea is about $6.0-6.50 \mathrm{t} \mathrm{ha}^{-1}$ (BRRI, 2016). Fertilization and weeding practices are very important factors for harvesting potential yield in rice. Attempts should also be taken to increase the yield per unit area through use of comparatively high yielding varieties. 
Bhuiyan et al.

The efficient $\mathrm{N}$ management can increase crop yield and reduce production cost. Inadequate and improper applications of $\mathrm{N}$ are now considered one of the major reasons for low yield of rice in Bangladesh. Weeds pose a major threat for increasing rice productivity. Uncontrolled weed growth caused significant loss of grain yield of rice. Any delay in weeding will lead to increased weed biomass as a result drastic reduction in yield. Moreover weed management in alternate wetting and drying (AWD) irrigation system revolved around grass weeds, predominantly Echinoachloa sp. AWD reduced broadleaf weed pressure and increase grass type weed and enhance overall weed growth and development which compete with rice and reduce yield. So, appropriate weed management strategies should be undertaken in AWD irrigation systems This study was undertaken to evaluate the yield response of BRRI hybrid dhan3 to different nitrogen levels and weed control methods under AWD irrigation system.

\section{Materials and methods}

The field studies were conducted during December 2014 to May 2015 at the experiment site of Bangladesh Rice Research Institute (BRRI) farm, Gazipur situated at 24099' North latitude and $90^{\circ} 40^{\prime}$ East longitude. The soil of the experimental site was clay loam of shallow brown terrace under Madhupur tract (AEZ 28), the experimental field classified as a Chhiata clay loam, hyperthermic Vertic Endoaquept. The initial chemical properties of the experimental site was presented in table 1.The planting crop was BRRI hybrid dhan3. The experiment consisted of two factors: A. N level viz., 0. 60, 120, 180 and $240 \mathrm{~kg}$ ha-1. B: weed control method viz., Pre emergence herbicide $+1 \mathrm{HW}$, Pre emergence + post emergence herbicide, Weed free by hand weeding and un weeded (control). Details of weeding treatments were presented in table2. Thirty days old seedlings were uprooted and transplanted on well puddled plots. The experiment was laid out in $\mathrm{RCB}$ design with three replications. The experimental plots were fertilized with TSP, Mop, Gypsum and Zine @ 127,120,112 and $15 \mathrm{~kg}$ ha-1, respectively according to BRRI recommended dose. Irrigation was done by AWD irrigation system. In AWD treatment, PVC tubes $(25 \mathrm{~cm}$ long and $10 \mathrm{~cm}$ in diameter) were installed to a depth of $15 \mathrm{~cm}$ below soil surface as described by Tuong et al. (2005). To obtained grain yield in individual plots six $\mathrm{m}^{2}$ area was selected. After sun drying moisture was adjusted at $14 \%$ and weighted and converted to $t \mathrm{ha}^{-1}$. One meter square area was selected at random in each plot for counting tiller and panicle number. Yield characters were calculated by selected $2 \times 2$ hill diagonally $(12$ hills) from each plot. The grains and sterile spikelets were separated by a seed sorter (Kiya Seisakusho LDT, model 1973, Tokyo, Japan). After separation, the grains and sterile spikelets were counted by an automatic counter (Nagoya, model DC 1-0, Japan). Then the numbers of grain panicle ${ }^{-1}$, weight of 1000 - grains was measured at $12 \%$ moisture and sterility (\%) was calculated.

The nitrogen use efficiency can be defined as the maximum economic yield produced per unit of nitrogen applied, absorbed or utilized by the plant to produce grain and straw. However, nitrogen use efficiency was determining as agronomic efficiency as described by Fageria and Baligar, 2001.

Agronomic efficiency $(\mathrm{AE})=\mathrm{Gf}-\mathrm{Gu} / \mathrm{Na}=\mathrm{kg} \mathrm{kg}^{-1}$

Where, Gf is the grain yield in the fertilized plot (kg), Gu is the grain yield in the unfertilized plot $(\mathrm{kg})$, and $\mathrm{Na}$ is the quantity of nutrient applied $(\mathrm{kg})$. 
Effect of Nitrogen Levels and Weed Management on Yield Performance of BRRI Hybrid Dhan3

\section{Optimization of $\mathrm{N}$ dose in different weed control methods}

The optimum $\mathrm{N}$ dose for BRRI hybrid dhan3 in different weed control methods was determined by regression the corresponding grain yield with the $\mathrm{N}$ rates: $Y=\mathrm{a}+b N+c N$. Where, $Y$ is rice yield (t/ha), $N$ is nitrogen dose (kg/ha), a is intercept (estimated yield without $N$ application), $b$ and $c$ are coefficients, respectively (Saleque et al., 2004). Differentiating $Y$ with respect to $N$ of the Eqn. gives the nitrogen dose for the maximum yield. The estimated nitrogen dose for maximum yield $\mathrm{N}=-\mathrm{b} / 2 \mathrm{c}$.

Weed biomass and number of weeds were assessed at 50 DAT from all experimental plots. Random samples were taken from within each plot using a $1 \mathrm{~m} \times 1 \mathrm{~m}$ quadrate (Kim and Moody, 1983). Weed species collected from within each quadrate were identified, listed and counted. Collected weeds were washed, sorted by species, dried at $70^{\circ} \mathrm{C}$ to constant weight and then weighed. For weed identification the nomenclature of Moody (1989) was used. Data were recorded included weed type and species, number of weeds and weed biomass etc.

\section{Summed dominance ratio (SDR)}

SDR of the weed species was computed using the following equation (Janiya and Moody, 1989):

$$
S D R=\frac{\text { Relative density }(\mathrm{RD})+\text { Relative dry weight }(\mathrm{RDW})}{2}
$$

Relative Dry Weight $(\mathrm{RDW})=\frac{\text { Dry weight of a given species }}{\text { Total dryweight }} \times 100$

Relative Density $(\mathrm{RD})=\frac{\text { Density of a given species }}{\text { Total density }} \times 100$

Weed control efficiency (WCE \%) and Weed Index (WI) was calculated by using subsequent formula according to Rao (1985).

Weed control Efficiency $(\mathrm{WCE})=\frac{\mathrm{wc}-\mathrm{wt}}{\mathrm{wc}} \times 100$

$\mathrm{WC}=$ Average weed weight per unit area in weedy check

$\mathrm{Wt}=$ Average weed count or dry weed weight per unit area in treated plot

Higher values of WCE indicate greater effectiveness of the herbicide

Weed Index $(\mathrm{WI})=\frac{\mathrm{YHW}-\mathrm{Yt}}{\mathrm{YHW}} \times 100$

Where,

$\mathrm{YHW}=$ Average yield of the crop in hand weeded, weed free plot or minimum weed competition plot

$\mathrm{Yt}=$ Average yield of the crop in plot under other weed control treatments.

Higher value of weed index indicates lower the yield and lower value of weed index indicate higher the yield. Data were analyzed statistically by statistical software crop stat 7.2. Analysis of variance and treatments were compared with least significant difference (LSD). Correlation and regression were done by Microsoft excel program. 
Bhuiyan et al.

\section{Results and discussion}

\section{Weed growth and weed control efficiency (\%)}

Interaction effect of weed management and $\mathrm{N}$ levels were not significant on weed number and dry matter weights of weeds but weed control treatments significantly reduced the weed population $\left(\mathrm{m}^{-2}\right)$ and weed dry matter weight $\left(\mathrm{gm}^{-2}\right)$ over the control (un weeded) (Table 3). Higher weed number and biomass were found in unweeded $\mathrm{x}$ different $\mathrm{N}$ levels and lower in different weed management $x \mathrm{~N}$ levels treatments. Pre emergence herbicide $+1 \mathrm{HW}$ and pre emergence herbicide + post emergence herbicide produced minimum number of weed and obtained minimum dry matter weight in different $\mathrm{N}$ levels. The weed control efficiency also revealed the superiority of the pre-emergence and post emergence herbicide application + hand weeding. The weed control efficiency of different weed management treatments ranged 78-93\%. The present experimental results of weed growth and WCE coroborates the findings from Akbar et al. (2011) who reported that the herbicide treatments resulted more than $80 \%$ reduction in weed density and 74-87 \% decrease in weed dry weight. Bhuiyan and Gazi (2010) reported that mefenacet + bensulfuron methyl 53\%WP @ 594g ai ha-1 lead to higher WCE (> $80 \%$ ) and lowest number and dry weight of weeds which ultimately resulted in higher yield attributes and grain yield of rice. The weed control efficiency of different weed management treatments ranged $78-93 \%$. The similar consequence of results was reported by Srinivasan et al., 2007.

\section{Relative proportions of different weed types}

The relative proportions of different weed types (broadleaf, grass and sedges) into total weed number and dry biomass on percentage basis are expressed in Figure 1. The contribution of grass, sedges and broadleaves were 37-42, 29-36 and 24-28\%, respectively in unweeded condition with different $\mathrm{N}$ treatments (Figure 1A). Therefore, grass was the dominant weed species in respect of weed density in unweeded condition $\left(\mathrm{T}_{11}-\mathrm{T}_{15}\right)$. Other weed $\mathrm{x} N$ management treatments contributed $25-31 \%$ grass, $31-45 \%$ sedges and $26-36 \%$ broadleaves. It seems sedges were not controlled well by different weed management treatments. Considering the proportion of weed biomass unweeded treatments contributed more than $40 \%$ grass, 28$32 \%$ sedges and $21-28 \%$ broadleaves (Figure 1B). Other weed $\times \mathrm{N}$ management treatments contributed $22-33 \%$ grass, $28-40 \%$ sedges and $25-44 \%$ broadleaves. Similar consequences of results were reported by Khaliq and Matloob (2011) in different competition period of weeds in rice.

\section{Weed Composition and Summed Dominance Ratio (SDR)}

The summed dominance ratio (SDR) is more informative than any single measure in reflecting the contribution of a species in the community. Figure 2 represents SDR values in unweeded condition. The effects of weed interfere at 45DAT recorded six weed species. The SDR of Echinochloa crus-galli was higher followed by Scirpus juncoides. Based on summed dominance ratio (SDR), the most dominant weed species could be arranged in the order of Echinochloa crus-galli $>$ Scirpus juncoides $>$ Cynodon dactylon $>$ Cyperus difformis $>$ Marselia minuta $>$ Monochoria vaginalis. Anwar et al. (2012) observed similar type of findings in aerobic rice system in different weed management systems. 
Effect of Nitrogen Levels and Weed Management on Yield Performance of BRRI Hybrid Dhan3

\section{Relationship of weed density, dry weight and weed index with rice grain yield and applied nitrogen}

Weed index is an ideal parameter to judge the effectiveness of weeding treatments. This is an indicator of reduction of crop yield due to presence of weeds in comparison with weed free plot or minimum weed competition plot. The lower weed index indicates higher effectiveness of a weeding treatment/ herbicide. The lowest weed index was obtained with Pre emergence herbicide $+1 \mathrm{HW}$ and pre emergence herbicide + post emergence herbicide. The weed indexes in unweeded plots were ranged 23-51\%. Figure 3 showed the relationship between weed index with dry matter weight (Figure 3A) and weed dry weight with rice grain yield (Figure 3B). Relationship of grain yield on weed index showed that the variation of grain yield was $42.42 \%$ due to weed index and the relationship was negative and linear. Relationship of weed dry matter weight and weed index showed linear relationship, which indicated an increasing weed biomass index that might contributed to lower yield. Singh et al. (2008) reported that the application of different herbicide treatments recorded lower weed index and gave similar yield to that of weed free plots. Relationship of grain yield and weed number (Figure 4A) indicated that the grain yield was significantly dependent on weed number and the relationship was linear and negative. Highest significant and negative correlation of grain yield with weed number was calculated where $\mathrm{R}^{2}$ value were $0.532^{* *}$ indicating the need for minimizing weed density to attain optimal rice grain yield. Figure $3 \mathrm{~B}$ also shows the relationship of grain yield with weed dry weight indicating significant negative correlation with grain yield with coefficient of determination of $0.5204^{* *}$.

Relationship of weed biomass and nitrogen dose in different weed control methods were quadric in nature (Figure 5).This figure indicates after application of a certain $\mathrm{N}$ dose weed biomass will not increase linearly. So, the relationship is quadric.

\section{Optimization of nitrogen dose in different weed control methods}

The variation of grain yield of BRRI hybrid dhan3 at different levels of $\mathrm{N}$ with different weed control methods was estimated through regression equation (Figure 6). The relationship of grain yield of weeding methods and applied nitrogen was quadric. The quadratic regression equation of BRRI hybrid dhan3 for Pre $\mathrm{EH}$, Post $\mathrm{EH}$ and $3 \mathrm{HW}$ were $\mathrm{y}=-0.00014 \mathrm{x}^{2}+$ $0.04842 \mathrm{x}+2.8840, \mathrm{R}^{2}=0.96^{*}, \mathrm{y}=-0.00011 \mathrm{x}^{2}+0.04166 \mathrm{x}+3.24229, \mathrm{R}^{2}=0.98^{*}$ and $\mathrm{y}=$ $-0.0001 x^{2}+0.0416 x+3.3214, R^{2}=0.98^{*}$ respectively. Nitrogen treatment accounted about 96,98 and,98\% variation in grain yield for different weed control methods of $\mathrm{PEH}, \mathrm{POEH}$ and $3 \mathrm{HW}$ respectively. The estimated optimum dose of nitrogen for Pre $\mathrm{EH}$ Post $\mathrm{EH}$ and $3 \mathrm{HW}$

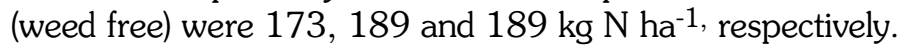

\section{Yield and yield contributing character}

Grain yield in $\mathrm{N}$ treatments were increased with increased $\mathrm{N}$ levels upto $180 \mathrm{~kg} \mathrm{~N}$ ha-1 in all weed management treatments (Table 4). Interaction effect of weed management $\mathrm{x} N$ levels on panicle $\mathrm{m}^{-2}$ and 1000- grain weight showed insignificant. The individual effect of weed management on panicle $\mathrm{m}^{-2}$ was also insignificant but effect of $\mathrm{N}$ management on panicle $\mathrm{m}^{-2}$ was significant.The highest grains panicle ${ }^{-1}$ (130) was observed in $3 \mathrm{HW}$ x N levels @ $180 \mathrm{~kg}$ ha $^{-1}$ while lowest grains panicle ${ }^{-1}(79)$ in unweeded $x$ control plots. The highest grain yield (7.62 t/ha) was obtained from $3 \mathrm{HW}$ x N levels @ 180kg ha-1 The lowest grain yield (2.59 t $\left.\mathrm{ha}^{-1}\right)$ was observed with unweeded $\mathrm{x}$ control $\mathrm{N}\left(0 \mathrm{~kg} \mathrm{ha}^{-1}\right)$ plots. Regression analyses carried out among yield and yield character to understand yield components association with grain yield 
Bhuiyan et al.

(Figure 7). A relationship between number of panicles $\mathrm{m}^{-2}$ and grain yield was highly significant $(\mathrm{P}<0.01)$ and linear, indicated 287 panicles $\mathrm{m}^{-2}$ are optimal to produce a grain yield of $7.61 \mathrm{t}$ $\mathrm{ha}^{-1}$ under the existing experimental conditions. On the other basis of $\mathrm{R}^{2}, 65.88 \%$ variation in grain yield could be accounted by panicle density. Similarly the relationship of grain yield with grains panicle $e^{-1}$ and 1000 -grain weight showed highly significant and linear. In regression analysis it is observed that $87.95 \%$ variation in grain yield could be accounted by grains panicle1 . Therefore, the lower yields would be explained by its lower panicle density, grain panicle ${ }^{-1}$ and 1000 -grain weight. Grain yield is also positively and highly correlated with harvest index. On the basis of $\mathrm{R}^{2}, 60.35 \%$ variation in grain yield could be explained by harvest index. Gravois and Helms (1992) reported that, among different yield components of rice, panicle density had the largest positive direct effect on rice yield. Shimul et al. (2015) observed that nitrogen and weed control had significant response on yield and yield components of hybrid rice

\section{Agronomic efficiency}

Agronomic efficiency was calculated and presented in Table 5. Interaction effect of weed and $\mathrm{N}$ levels significantly varied agronomic efficiency. In unweeded condition agronomic efficiency was in very low range of 4-13. Agronomic efficiency was 23 in $3 \mathrm{HW}$ with $180 \mathrm{~kg} \mathrm{~N}^{-1}$.in highest yield level and Agronomic efficiency ranged $23-28$ in $120-180 \mathrm{~kg} \mathrm{~N}^{-1}$ with different weed management options. Agronomic nitrogen use efficiency varied 15-25 kg grain per $\mathrm{kg}$ of applied $\mathrm{N}$ depending on season, yield level, and the rate and timing of $\mathrm{N}$ application in different rice culture (Fageria and Baligar, 2001).

\section{Conclusion}

From the study it may be concluded that pre emergence application of Prefer 18WP (bensulfuran methyl + acetachlor) and post emergence application of Dhaman 300wp (bispyribac sodium 18\% + bensulfuran methyl 12\%) following one hand weeding resulted in better weed control and grain yield of BRRI hybrid dhan3 under AWD irrigation condition. The highest grain yield $\left(7.61 \mathrm{t} \mathrm{ha}^{-1}\right)$ was found from the combination of applying the nitrogen ( ) $180 \mathrm{~kg} \mathrm{ha}^{-1}$ and 3 hand weedings. Comparable higher grain yield was obtained from the combination of pre emergence herbicide + one hand weeding with $180 \mathrm{~kg} \mathrm{~N}$ ha $\left(7.48 \mathrm{t} \mathrm{ha}^{-1}\right)$ and the combination of pre + post emergence herbicide with $180 \mathrm{~kg} \mathrm{~N} \mathrm{ha}^{-1}\left(7.56 \mathrm{t} \mathrm{ha}^{-1}\right)$.

Table 1. Initial soil chemical properties at $0-15 \mathrm{~cm}$ soil depth in the experimental plot

\begin{tabular}{|c|c|}
\hline Soil property & Value \\
\hline Soil pH & 6.65 \\
\hline Organic matter & $1.94 \%$ \\
\hline Total $\mathrm{N}$ content & $0.08 \%$ \\
\hline Available phosphorus (P) & $\begin{array}{l}10.15 \mathrm{mg} \mathrm{kg}^{-1} \\
\left(0.5 \mathrm{M} \mathrm{NaHCO}_{3} \text { extracted) }\right.\end{array}$ \\
\hline Exchangeable potassium (K) & $\begin{array}{l}0.17 \mathrm{meq} / 100 \mathrm{~g} \text { soil } \\
\text { (Neutral } 1.0 \mathrm{~N} \mathrm{NH}_{4} \mathrm{OAc} \text { extracted) }\end{array}$ \\
\hline Available sulfur (S) & $20 \mathrm{mg} \mathrm{kg}^{-1}\left[\mathrm{Ca}\left(\mathrm{H}_{2} \mathrm{PO}_{4}\right)_{2}\right.$ extracted $]$ \\
\hline Available zinc (Zn) & $2.92 \mathrm{mg} \mathrm{kg}^{-1}(0.01 \mathrm{~N} \mathrm{HCl}$ extracted $)$ \\
\hline
\end{tabular}


Effect of Nitrogen Levels and Weed Management on Yield Performance of BRRI Hybrid Dhan3

Table 2. Description of weed control methods

\begin{tabular}{|c|c|c|c|c|}
\hline \multirow[t]{2}{*}{ Weed control methods } & \multicolumn{4}{|c|}{ Description } \\
\hline & Name of herbicide & Dose & $\begin{array}{l}\text { Time of } \\
\text { application }\end{array}$ & $\begin{array}{c}\text { Time of hand } \\
\text { weeding }\end{array}$ \\
\hline $\begin{array}{l}\text { Pre emergence } \\
\text { herbicide (PEH) } \\
\text { followed by one hand } \\
\text { weeding (1HW) }\end{array}$ & $\begin{array}{l}\text { Prefer 18WP((Bensulfuran } \\
\text { Methyl + Acetachlor) }\end{array}$ & $\begin{array}{l}750 \mathrm{~g} \\
\mathrm{ha}^{-1}\end{array}$ & $4 \mathrm{DAT}$ & 50DAT* \\
\hline $\begin{array}{l}\text { Pre emergence } \\
\text { herbicide } \\
\text { followed by preEH) } \\
\text { emergence herbicide } \\
\text { (POEH) }\end{array}$ & $\begin{array}{l}\text { Prefer 18WP ((Bensulfuran } \\
\text { Methyl Acetachlor) fb } \\
\text { Dhaman 300wp (Bispyribac } \\
\text { sodium 18\% + Bensulfuran } \\
\text { methyl 12\%) }\end{array}$ & $\begin{array}{l}150 \mathrm{~g} \\
\mathrm{ha}^{-1}\end{array}$ & $\begin{array}{l}4 \text { DAT } \\
\text { followed } \\
\text { by } 22 \\
\text { DAT }\end{array}$ & - \\
\hline Un weeded (UW) & - & - & - & - \\
\hline $\begin{array}{l}\text { Weed free (WF) by } 3 \\
\text { hand weedings }\end{array}$ & - & - & - & $\begin{array}{l}\text { 15, } 30 \text { and } \\
\text { 50DAT }\end{array}$ \\
\hline
\end{tabular}

DAT $=$ Days After Planting

Table 3. Interaction effect of weed control methods and $\mathrm{N}$ levels on weed number, dry matter weight, and weed control efficiency (\%) of BRRI hybrid dhan3 during Boro 2014-15

\begin{tabular}{|c|c|c|c|}
\hline Treatment & $\begin{array}{l}\text { Weed m-2 } \\
\text { (No.) }\end{array}$ & $\begin{array}{l}\text { Weed dry matter } \\
\text { weight }\left(\mathrm{gm}^{-2}\right)\end{array}$ & $\begin{array}{r}\text { *Weed control efficiency } \\
(\%)\end{array}$ \\
\hline Weed management & \multicolumn{3}{|c|}{$\mathrm{N}$ levels $\left(0 \mathrm{~kg} \mathrm{ha}^{-1}\right)$} \\
\hline Pre $\mathrm{EH}+1 \mathrm{HW}$ & 16 & 4.82 & 78 \\
\hline Pre $\mathrm{EH}+$ post $\mathrm{EH}$ & 17 & 4.44 & 80 \\
\hline Un weeded & 46 & 22.87 & \\
\hline \multicolumn{4}{|c|}{$\mathrm{N}$ levels ( $60 \mathrm{~kg} \mathrm{ha}^{-1}$ ) } \\
\hline Pre $\mathrm{EH}+1 \mathrm{HW}$ & 14 & 2.71 & 90 \\
\hline Pre $\mathrm{EH}+$ post $\mathrm{EH}$ & 16 & 2.55 & 91 \\
\hline Un weeded & 49 & 29.44 & \\
\hline \multicolumn{4}{|c|}{$\mathrm{N}$ levels $\left(120 \mathrm{~kg} \mathrm{ha}^{-1}\right)$} \\
\hline Pre $\mathrm{EH}+1 \mathrm{HW}$ & 13 & 2.08 & 93 \\
\hline Pre $\mathrm{EH}+$ post $\mathrm{EH}$ & 16 & 2.36 & 92 \\
\hline Un weeded & 48 & 31.25 & \\
\hline \multicolumn{4}{|c|}{ N levels $\left(180 \mathrm{~kg} \mathrm{ha}^{-1}\right)$} \\
\hline Pre $\mathrm{EH}+1 \mathrm{HW}$ & 14 & 2.11 & 93 \\
\hline Pre $\mathrm{EH}+$ post $\mathrm{EH}$ & 15 & 2.21 & 92 \\
\hline Un weeded & 48 & 30.81 & \\
\hline \multicolumn{4}{|c|}{$\mathrm{N}$ levels $\left(240 \mathrm{~kg} \mathrm{ha}^{-1}\right)$} \\
\hline Pre $\mathrm{EH}+1 \mathrm{HW}$ & 14 & 2.23 & 92 \\
\hline Pre $\mathrm{EH}+$ post $\mathrm{EH}$ & 17 & 2.64 & 90 \\
\hline Un weeded & 46 & 30.73 & \\
\hline \multicolumn{4}{|l|}{ LSD(.05) } \\
\hline WM & 3.11 & 4.08 & - \\
\hline $\mathrm{N}$ levels & ns & ns & - \\
\hline WM $\times \mathrm{N}$ levels & ns & ns & - \\
\hline $\mathrm{CV}(\%)$ & 16.0 & 47.3 & - \\
\hline
\end{tabular}

* \% Weed Control Efficiency was calculated over no weeding with dry matter weight basis 
Bhuiyan et al.
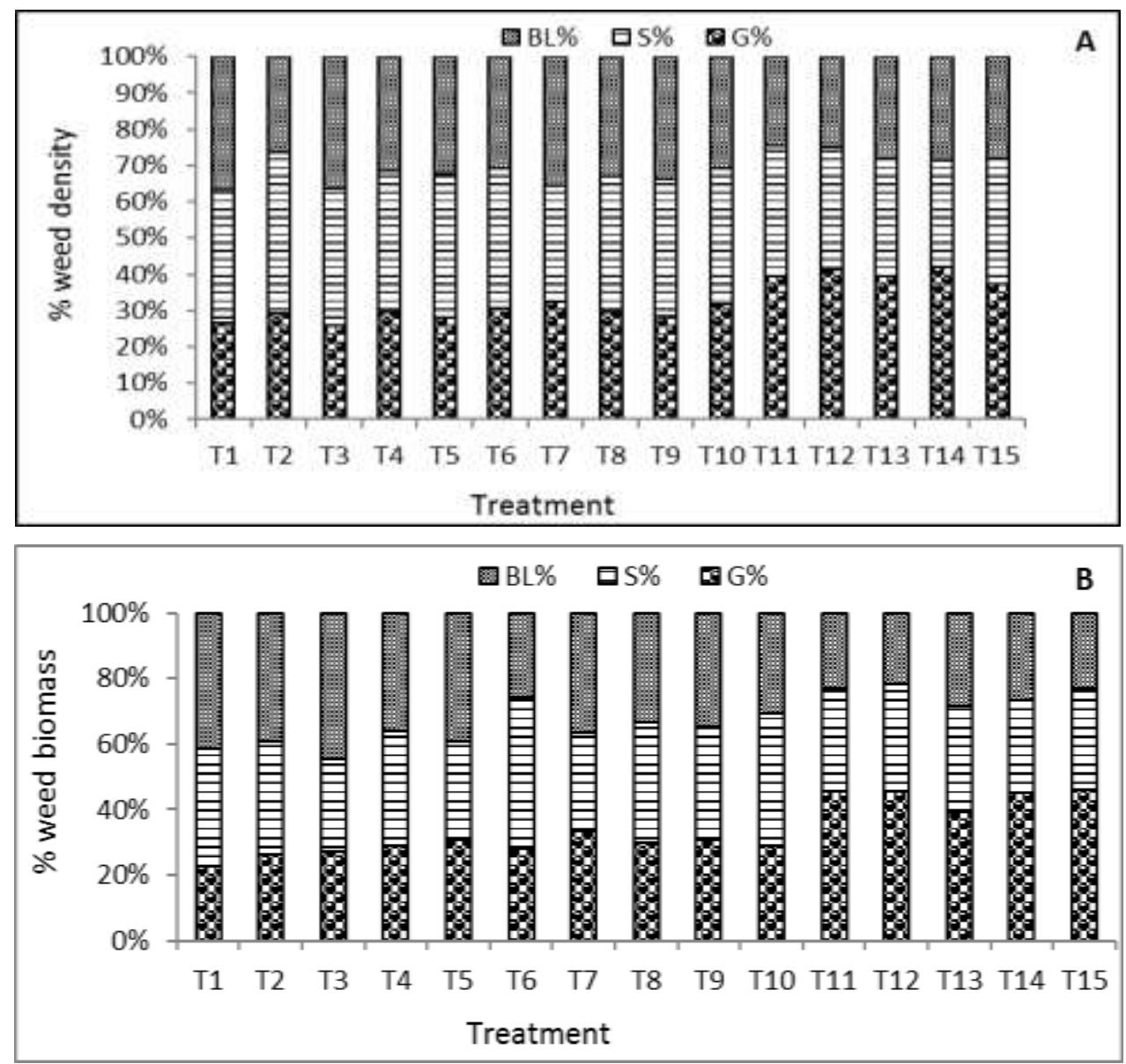

Fig. 1. Relative proportion of different weed types in total weed density (A) and biomass (B) over different weed management during 2014-15

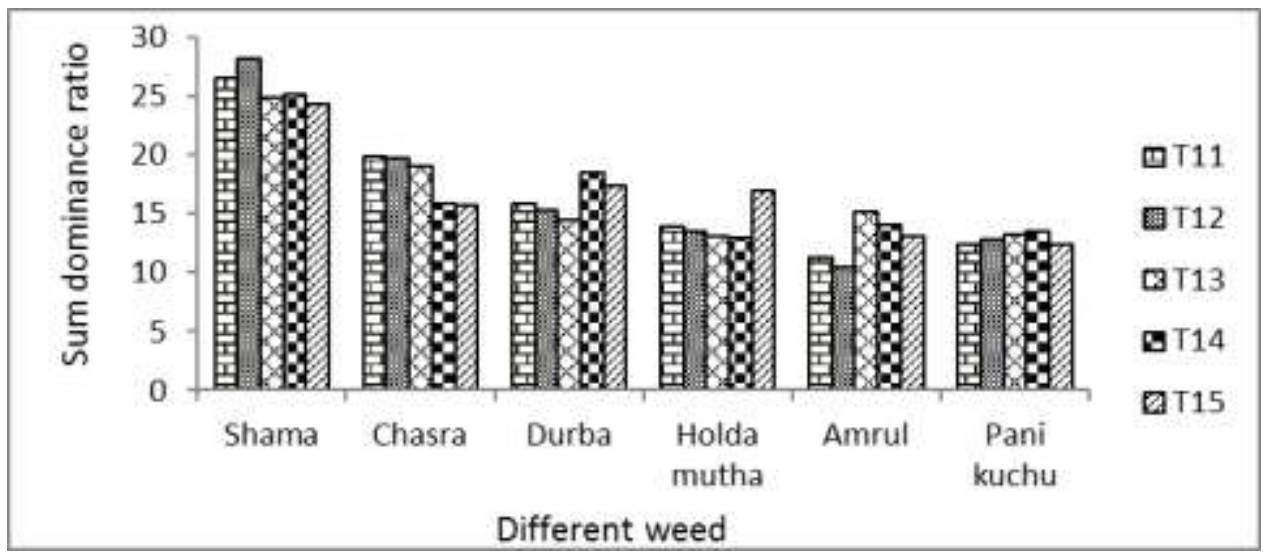

Fig. 2. Weed dominance ranking (SDR) in BRRI hybrid dhan3 in unweeded condition during 2014-15 
Effect of Nitrogen Levels and Weed Management on Yield Performance of BRRI Hybrid Dhan3
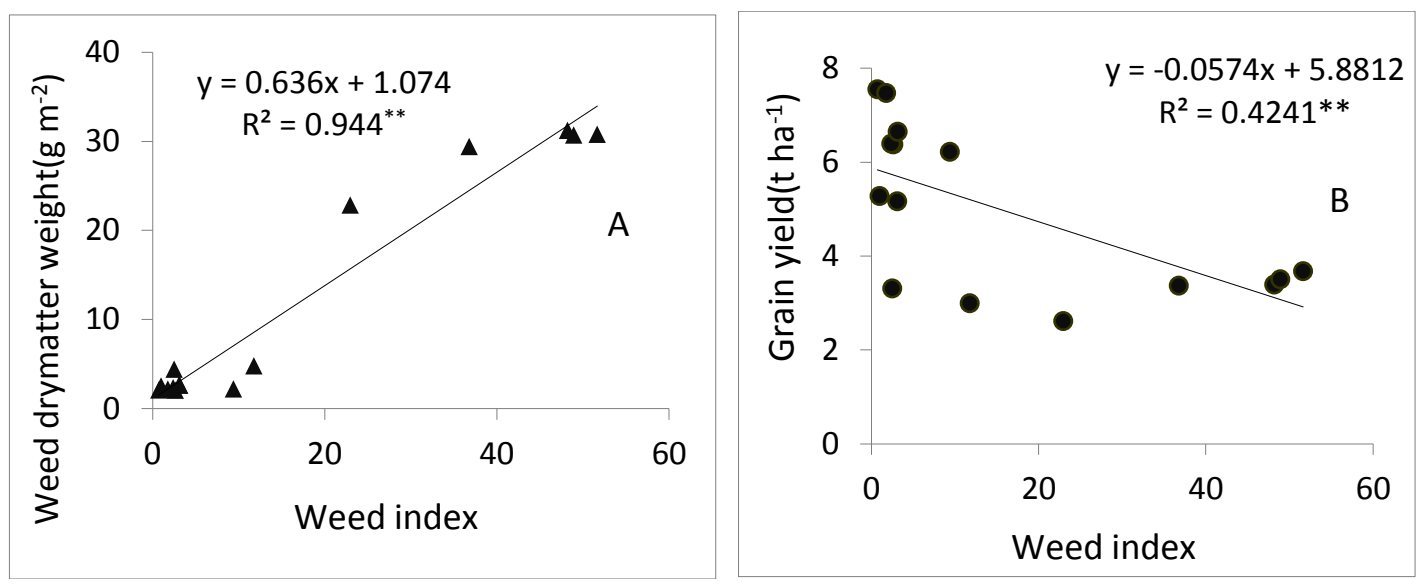

Fig. 3. A. Relationship of weed dry matter weight with weed index. B. Dependence of grain yield on weed index

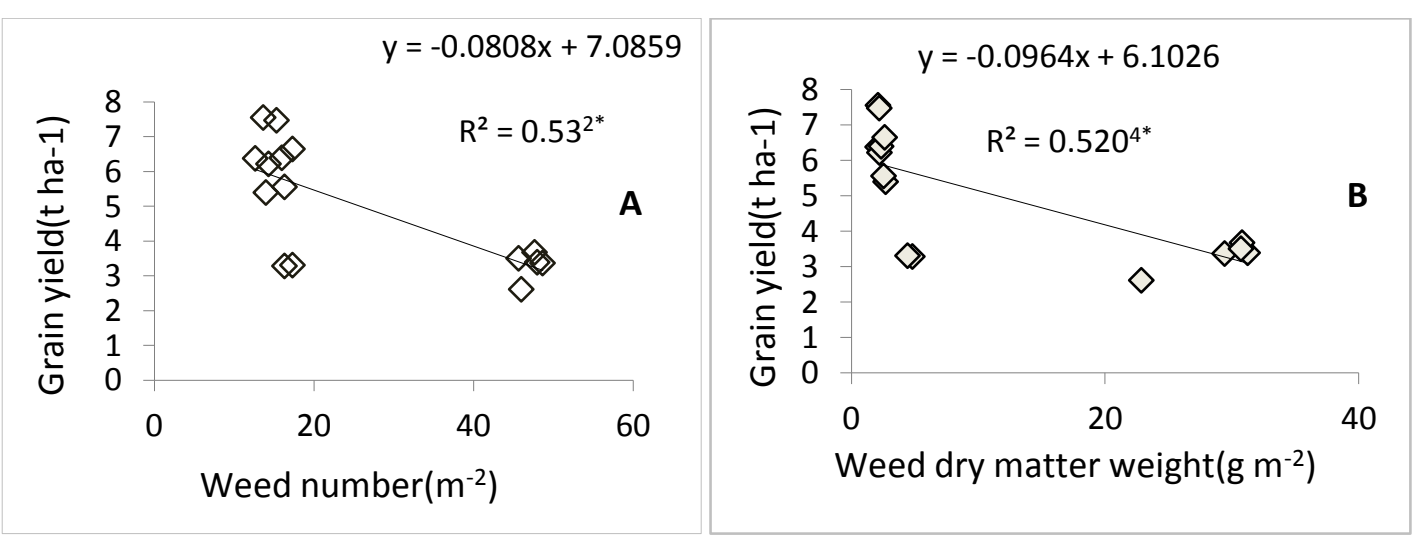

Fig. 4. Relationship between grain yield with weed number and weed dry matter weight

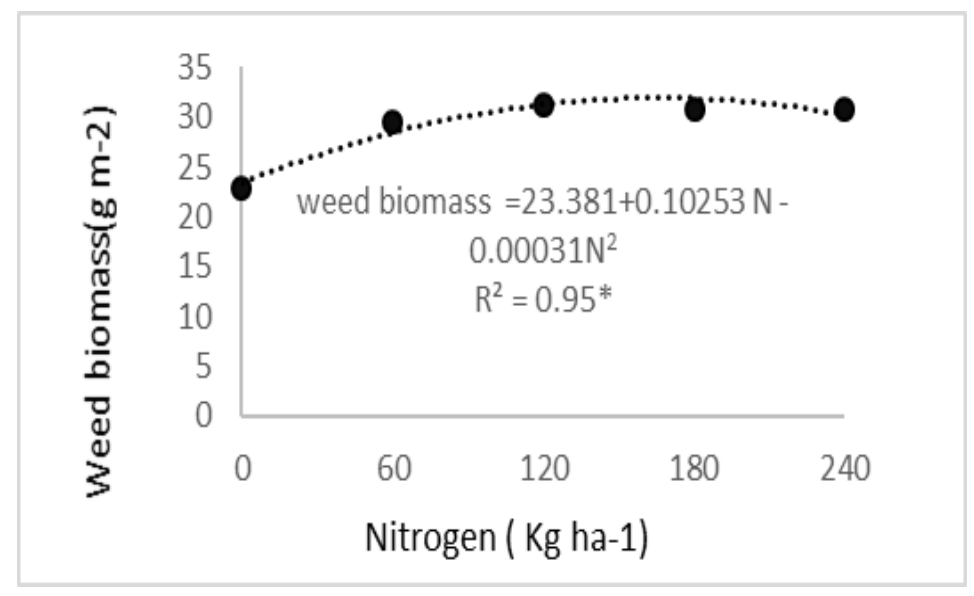

Fig. 5. Relationship of weed biomass and nitrogen dose 
Bhuiyan et al.
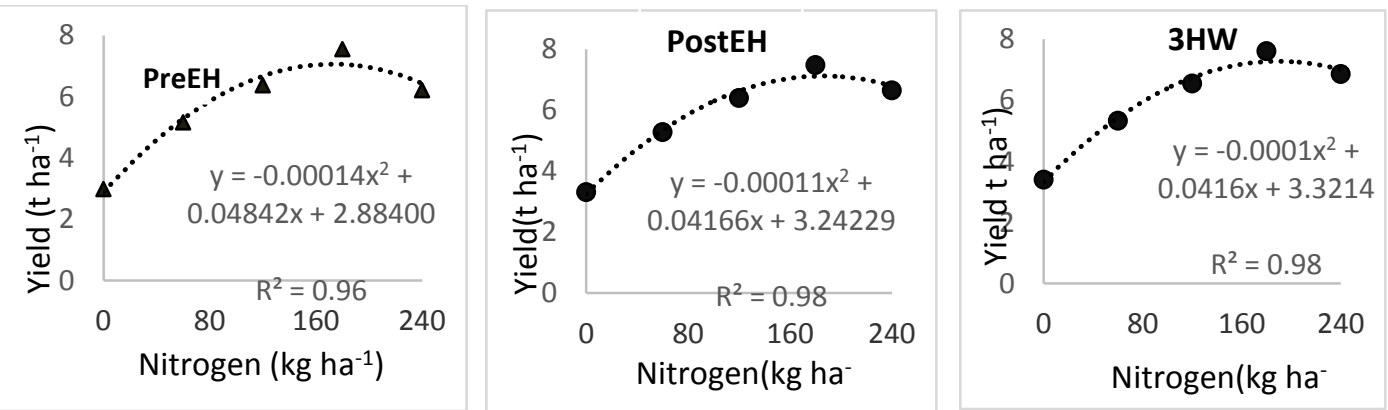

Fig. 6. Optimization of nitrogen dose in different weed control methods based on grain yield

Table 4. Interaction effect of weed management and $\mathrm{N}$ levels on yield and yield characters of BRRI hybrid dhan3

\begin{tabular}{|c|c|c|c|c|}
\hline Treatment & $\begin{array}{c}\text { Panicle } \\
\mathrm{m}^{-2}\end{array}$ & $\begin{array}{c}\text { Grains } \\
\text { panicle }^{-1}\end{array}$ & $\begin{array}{c}\text { 1000- grain } \\
\text { weight(g) }\end{array}$ & $\begin{array}{l}\text { Grain yield } \\
\left(\mathrm{t} \mathrm{ha}^{-1}\right)\end{array}$ \\
\hline Weed Management & \multicolumn{4}{|c|}{$\mathrm{N}$ levels $\left(0 \mathrm{~kg} \mathrm{ha}^{-1}\right)$} \\
\hline Pre $\mathrm{EH}+1 \mathrm{HW}$ & 166 & 85 & 27.00 & 2.99 \\
\hline Pre $\mathrm{EH}+$ post $\mathrm{EH}$ & 167 & 82 & 26.29 & 3.31 \\
\hline Weed free (3 HW) & 177 & 93 & 26.43 & 3.40 \\
\hline Un weeded & 181 & 79 & 26.34 & 2.59 \\
\hline \multicolumn{5}{|c|}{$\mathrm{N}$ levels $\left(60 \mathrm{~kg} \mathrm{ha}^{-1}\right)$} \\
\hline Pre $\mathrm{EH}+1 \mathrm{HW}$ & 181 & 79 & 26.34 & 2.59 \\
\hline Pre $E H+$ post $E H$ & 210 & 98 & 27.27 & 5.28 \\
\hline Weed free (3 HW) & 215 & 103 & 27.05 & 5.33 \\
\hline Un weeded & 209 & 86 & 26.96 & 3.37 \\
\hline \multicolumn{5}{|c|}{$\mathrm{N}$ levels $\left(120 \mathrm{~kg} \mathrm{ha}^{-1}\right)$} \\
\hline Pre $\mathrm{EH}+1 \mathrm{HW}$ & 230 & 102 & 27.84 & 6.38 \\
\hline Pre $E H+$ post $E H$ & 253 & 110 & 27.59 & 6.40 \\
\hline Weed free (3 HW) & 227 & 113 & 27.23 & 6.55 \\
\hline Un weeded & 216 & 88 & 26.99 & 3.39 \\
\hline \multicolumn{5}{|c|}{$\mathrm{N}$ levels $\left(180 \mathrm{~kg} \mathrm{ha}^{-1}\right)$} \\
\hline Pre $\mathrm{EH}+1 \mathrm{HW}$ & 287 & 126 & 28.07 & 7.56 \\
\hline Pre $\mathrm{EH}+$ post $\mathrm{EH}$ & 276 & 123 & 27.92 & 7.48 \\
\hline Weed free (3 HW) & 285 & 130 & 28.01 & 7.61 \\
\hline Un weeded & 236 & 90 & 27.09 & 3.68 \\
\hline \multicolumn{5}{|c|}{ N levels ( $240 \mathrm{~kg} \mathrm{ha}^{-1}$ ) } \\
\hline Pre $\mathrm{EH}+1 \mathrm{HW}$ & 295 & 105 & 26.77 & 6.22 \\
\hline Pre $E H+$ post $E H$ & 286 & 103 & 26.66 & 6.65 \\
\hline Weed free (3 HW) & 300 & 105 & 26.87 & 6.86 \\
\hline Un weeded & 248 & 87 & 26.36 & 3.87 \\
\hline \multicolumn{5}{|l|}{$\mathrm{LSD}(0.05)$} \\
\hline WM & ns & 3.49 & ns & 0.31 \\
\hline $\mathrm{N}$ levels & 22.56 & 3.90 & ns & 0.35 \\
\hline WM $\times \mathrm{N}$ levels & ns & 7.80 & ns & 0.69 \\
\hline CV (\%) & 11.70 & 4.7 & 2.30 & 8.1 \\
\hline
\end{tabular}


Effect of Nitrogen Levels and Weed Management on Yield Performance of BRRI Hybrid Dhan3
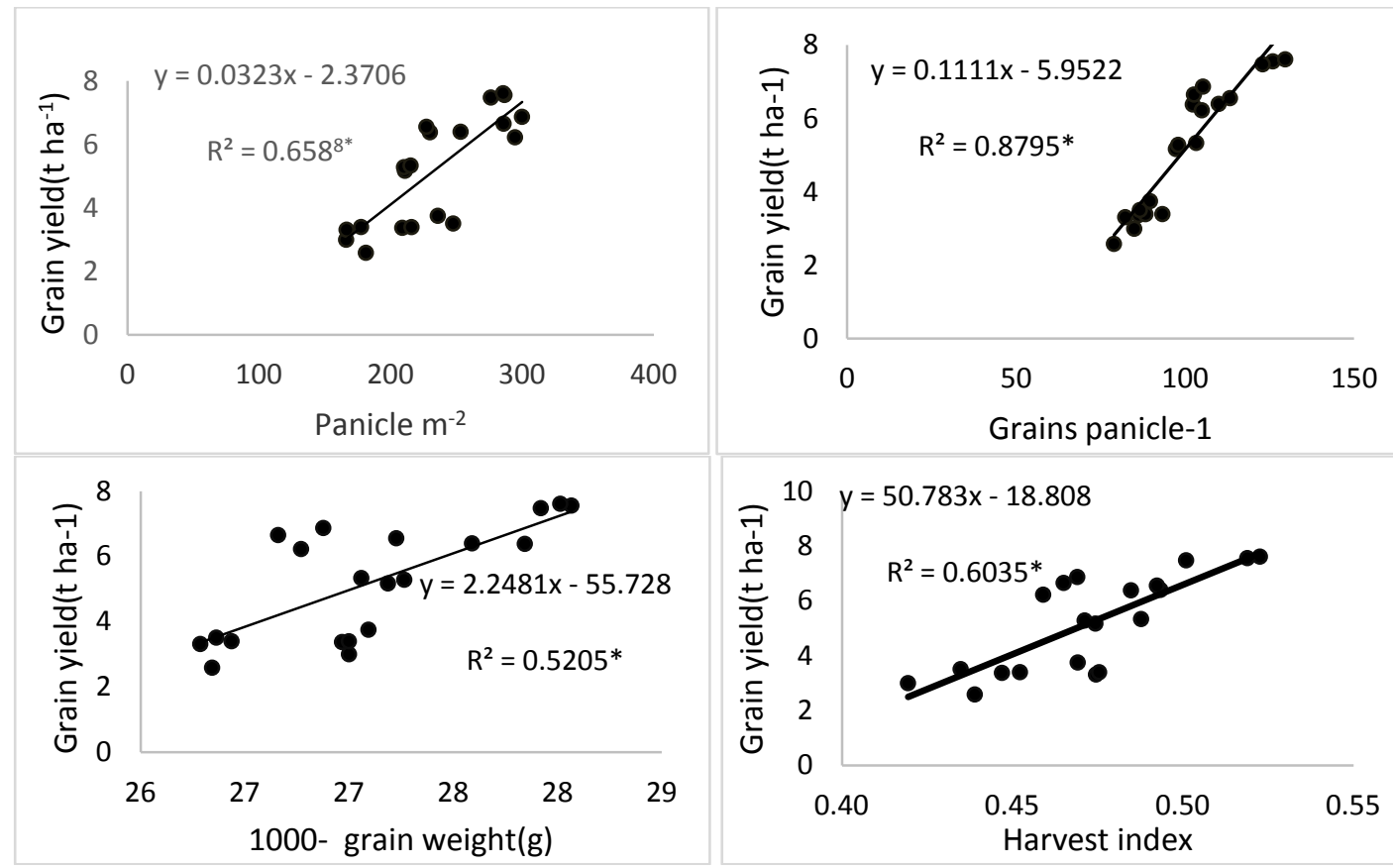

Fig. 7. Relationship of grain yield with yield components by weed management and nitrogen levels

Table 5. Agronomic efficiency of BRRI hybrid dhan3 as affected by weed management and nitrogen levels interaction

\begin{tabular}{lcc}
\hline Weed management & Nitrogen levels $\left(\mathrm{kg} \mathrm{N} \mathrm{ha}^{-1}\right)$ & Agronomic Efficiency \\
\hline Pre emergence & 60 & 35 \\
herbicide+ 1HW & 120 & 28 \\
& 180 & 25 \\
& 240 & 13 \\
\hline Pre emergence & 60 & 33 \\
herbicide+ post & 120 & 26 \\
emergence herbicide & 180 & 23 \\
& 240 & 14 \\
\hline 3 Hand weeding & 60 & 32 \\
& 120 & 26 \\
& 180 & 23 \\
& 240 & 14 \\
\hline Un weeded & 60 & 13 \\
& 120 & 7 \\
& 180 & 6 \\
& 240 & 4 \\
\hline LSD(0.05) & Weed management & 2.54 \\
& N levels & 2.54 \\
CV(\%) & - & 5.08 \\
\hline
\end{tabular}


Bhuiyan et al.

\section{References}

AIS (Agricultural Information Service). (2015). Krishi Diary (In Bangla). Agril. Inform. Ser. Khamarbari, Farmgate, Dhaka, Bangladesh. p.13

Akbar, N., Ehsanullah, J. Khawar, M. A. Ali. 2011. Weed management improves yield and quality of direct seeded rice. AJCS. 5(6): 688-694

Anwar, M. P, A. S. Juraimi, B. Samedani, A. Puteh, A. Man. 2012. Critical period of weed control in aerobic Rice. The Scientific World Journal 2012: 1-10.

Bhuiyan, M. K. A., G. J. U. Ahmed 2010: Performance of mefenacet + bensulfuron methyl 53\% Wp against weed suppression in transplanted paddy. Pak. J. Weed Sci. Res. 16 (2): 181187.

BRRI (Bangladesh Rice Research Institute). (2016). Adhunik Dhaner Chash (in bengali). Bangladesh Rice Research Institute, Joydebpur, Gazipur. p.5.

Fageria, N. K., V. C. Baligar.2001.Lowland rice response to nitrogen fertilization. Communications in Soil Science and Plant Analysis 32: 1405-1429.

Fageria, N. K., V. C. Baligar, C. A. Jones. 1997. Growth and Mineral Nutrition of Field Crops. 2nd Ed.; Marcel Dekker, Inc.: New York.

Janiya, J. D., K. Moody 1989: Weed populations in transplanted and wet-seeded rice as affected by weed control method. Tropical Pest Management 35(1): 8-11

Khaliq, A. and A. Matloob. 2011. Weed-crop competition period in three fine rice cultivars under direct-seeded rice culture. Pak. J. Weed Sci. Res. 17(3): 229-243.

Kim, S. C., K. Moody. 1983. Minimum sampling size and minimum quadrat number for weed data collection in transplanted rice. J. Korean Soc. Crop Sci. 28(3): 319-322.

Moody, K. 1989. Weeds reported in rice in South and South East Asia.Los Banos, Philippines.International Rice Research Institute. pp87-102

Rao, A. N. 1985. Weed vegetation analysis. Lecture presented to participants attending the Weed Science Workshop, IRRI, Los Baños, Philippines.

Shimul, C. S., M. H. Ali, P. K. Biswas., R. Chakraborty, A. Amin and S. Khandker.2015. Contribution of nitrogen and methods of weeding on the yield components and yield of hybrid boro rice (HEERA 4). European academic research. Vol.II. Issue 12.

Singh, S., J. K. Ladha, R. K. Gupta, L. Bhushan, A. N. Rao. 2008. Weed management in aerobic rice systems under varying establishment methods. Crop Prot. 27: 660-671.

Srinivasan, E. K., S. Natarajan, M. Ganapathy and, K. Arivazhagan. 2007. Effect of nitrogen levels and weed management in hybrid rice. Oryza 44(4): 363-365.

Saleque, M.A., M.J. Abedin, N.I. Bhuiyan, S.K. Zaman and G. M. Panaullah. 2004. Long-term effects of inorganic and organic fertilizer sources on yield and nutrient accumulation of lowland rice. Field Crop Res. 86: 53-65.

Tuong, T. P., B. A. M. Bouman and M. Mortimer, 2005. More rice, less water: integrated approaches for increasing water productivity in irrigated rice-based systems in Asia. Plant Production Science 8: 231-241. 